\title{
Pharma patents in Europe: where are we going?
}

\author{
“In January 2008, the European Commission launched a sector inquiry into European \\ pharmaceutical markets ... with the aim of examining the reasons why fewer new medicines \\ were brought to market and why generic entry seemed to be delayed in some cases."
}

In January 2008, the European Commission launched a sector inquiry into European pharmaceutical markets under the European Communities (EC) competition rules, with the aim of examining the reasons why fewer new medicines were brought to market and why generic entry seemed to be delayed in some cases. In November 2008, a preliminary report was published [101].

There is no indication as to why fewer new medicines have hit the market and no essential proposals have been made to remedy this situation. However, the report contains accusations that originator companies deliberately delay generic entries through the misuse of the patent system, 'ever-greening' patents and by the enforcement of patent rights in court. Reading the report, one could almost believe that 'secondary' patents not just covering the chemical compound (new chemical entity) but also pharmaceutical formulations, polymorphic forms, particular salts, combinations of compounds, second and further medical use, as well as manufacturing processes, for instance, are bad, because they contribute to delaying generic entry.

\section{"There is no such thing as 'ever-greening' patents: you cannot extend a patent by re-filing it."}

There is no such thing as 'ever-greening' patents: you cannot extend a patent by refiling it. All the secondary patents protect genuine inventions (novel and non-obvious), otherwise they would not have been granted. In other words, once the original patent (and corresponding supplementary protection certificates) have expired after the maximum possible time-frame between filing the patent application and expiry of the supplementary protection certificate after 20 plus 5 years, everybody is free to copy the invention. However, the copyist may not have access to the improvements protected by secondary patents. Decisions by generic companies on when to enter the market are reached after careful analysis, where one of the factors may include the ability to successfully compete based on the drug as originally patented with the drug form incorporating improvements covered by secondary patents. The generic drug companies very often prefer not to try to get to the market with an original, expired patent without later improvements, because they would not survive on the market. If the secondary patents were not innovative, then they would not represent a barrier to market entry after expiration of the original patent!

The report is an excellent source of information on pharmaceutical patenting in Europe from 2000 to 2007 . No surprises, but a confirmation of what everybody in the field already knew: patents are there to protect investment in innovation. Innovations are not only 'new chemical entities', but also improvements in using and applying existing chemical compounds as pharmaceuticals. And it is fair to give patent protection for such improvements if they are novel and nonobvious, because they benefit the patient in need of such improved medication.

Somehow, the report makes one believe that patent offices should set a higher patentability standard for granting 'secondary' patents in the pharmaceutical field. However, the principles of patenting must be the same and independent of any potential impact a patent may have. It is just not true that pharmaceutical patents stand out negatively. There are patents for basic inventions and for incremental improvements in all fields of technology, and rightly so. Protection for incremental improvements is needed in the same way as we need protection for breakthrough inventions. Research is the fuel for progress: if society is not willing to award protection for the research results, nobody will invest in them.

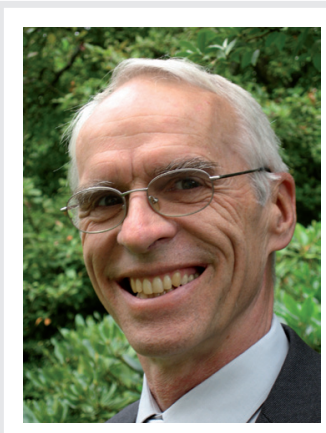

Konrad Becker

European Patent Attorney,

Aeschenvorstadt 24,

PO Box 318, CH-40I0 Basel, Switzerland

Tel.: +41 61 2799599

Fax: +41 61 2799596

E-mail: mail@beckerpatent.ch 
It is also no surprise that originator pharmaceutical companies try to use the patent system to their benefit. The companies are there to make profits. Nothing is wrong with this principle and, of course, in the same way generic companies want to make profit. Reading the European Commission report, one could believe that generic companies are only there to avoid costs for patients, health insurance and governments. Originator and generic companies have their place in the health systems and it is no surprise in a market economy that their way of making business is dictated by the desire to make profit. The legislators are there to set the frame for doing business. It is both refreshing and revealing to read the comments made by judge Sir Robin Jacob at the press conference to present the preliminary report [102]. He put the report into perspective, demonstrating that it did not actually find anything surprising or new, and that the proposals from the European Commission service for changing the patent law will not actually remedy the situation!

'Raising the bar' is a new buzz word in patenting, one on which the European Patent office's 2007 report focuses [103]. But it is not 'raising the bar on patenting' but 'raising the bar on patent quality'. There we can all agree: the process of patenting needs all our efforts to provide quality and fairness, both for breakthrough inventions and incremental improvements. The so-called 'secondary' patents for pharmaceuticals will have to stay and continue to play an important role in the progress of the pharma industry.

\section{"The Community patent is greatly needed to put European companies on an equal footing with their competitors in the USA and Japan."}

Other patent aspects revealed by the preliminary report on the sector inquiry into European pharmaceutical markets seem to be less contentious [101]. Pharmaceutical originator companies, generic companies and the European Commission services all support a Community patent and a unified European jurisdiction on patents. Where do we stand?

We have a common market, a Community trademark, a Community design, but no Community patent. Discussions started in the 1960s and, although the European bundle patent was put in place in 1973 and the European Patent Office started to function in 1978, the corresponding Community patent never got off the ground. Expectations were high when a new EC Commission initiative started in 1997 (Green Paper on the Community patent and the patent system in Europe [104]), followed by the 2000 proposal on a Regulation for a Community patent [1], and again in 2003 with the 'common position', which was welcomed as a breakthrough after 30 years of deliberation [105,106].

However, the obstacles remain the same: linguistic, jurisdictional and financial. This was clearly visible when the European Commission presented the results of a consultation on the future patent policy in Europe in 2006 [107]. The Community patent is greatly needed to put European companies on an equal footing with their competitors in the USA and Japan. A patent for the European market is five- to ten-times more expensive than a patent for the USA. My prediction is that the Community patent is still years away. The politicians should talk to the most important stakeholders - those who use the system. It requires a bold step forward, not a watering down of the concept by compromising on each and every aspect, trying to save national traditions and peculiarities as well as income to translators, local patent attorneys and national patent offices. The compromise Community patent currently under discussion will still require substantial costs for translations and annual fees. If the Community patent is too expensive and fails to bring legal certainty, the system will just not be used.

The fundamental opposition of some EC member states can only be handled by moving ahead with those member states willing to support truly European solutions. A first step forward is demonstrated by the London Agreement, which took effect on 1 May 2008 [108]. Several countries no longer require translations of the patent description into their national language, if an English text is available. France, Germany, Switzerland, Liechtenstein, Luxembourg, Monaco and the UK do not require any translation, since the claims on-grant of the patent are already provided in German, French and English, and the countries mentioned accept patent specifications in any of these three languages. Croatia, Denmark, Iceland, Latvia, The Netherlands, Sweden and Slovenia require a translation of the claims into their national language, but no translation of the whole patent (if provided in English) as in the past. This is a first step towards reducing the cost of patenting in Europe. 
A further remarkable initiative is the proposal for a European Patent Litigation Agreement [109]. It is now shelved because the European Commission opposed the initiative of some of its member states, and substituted the proposed agreement with their own proposal for a Community Patent Court [110]. The project is still under active deliberation but neither the Slovenian nor the French presidencies were successful in pushing it forward. The project faces stiff opposition from some EC member states, and it will not become a reality in the near future, despite strong support from many users, including the pharmaceutical industry and notable judges. The existing fragmented system, with enforcement of patents in each country according retrospective national traditions, is burdensome and costly for originators and generics alike. The industry needs an efficient high-quality court system providing fast decisions and legal certainty.

\section{"The industry needs an efficient high-quality court system providing fast decisions and legal certainty."}

A point of concern for all users of the European patent system is the time lost in opposition and appeal proceedings in the European Patent Office. Both originators and generics would prefer to have early decisions from the European Patent Office, but the back$\log$ is growing rather than diminishing and a solution is not in sight. Since the prosecution of patent applications also requires considerable time, divisional applications may be sitting around for extended periods of time, creating legal uncertainty because it is not clear whether these divisionals will ever be granted. It is not the fault of patent applicants to profit from the delay in decisions for grant or final refusal of divisional applications in the European Patent Office as one could believe when reading the
EC pharmaceutical sector inquiry report. Divisional applications are designed to cover inventions that are related, but that are different from inventions in the basic application. The principles of divisional applications are laid down in the Paris Convention and applied by all patent offices worldwide in all fields of technology.

One final positive note from the European patent system. The revised European Patent Convention took effect on 13 December 2007 [111]. Second (and further) medical use patents are now based on the revised Convention and not just on a shaky interpretation of the Convention by the Enlarged Board of Appeal. This increases legal certainty, but does not actually alter the scope for second (and further) medical use patents. Streamlining the text of the Convention, simplifying wherever possible and moving technical details into the regulations, will benefit originators and generics alike. The possibility of a central limitation of European patents by the patentee and a review of decisions made by the Board of Appeal in case of substantial procedural violations are also welcome.

\section{Financial \& competing interests disclosure}

From 1983 to 2001, Konrad Becker worked as a patent attorney in the pharmaceutical industry, and from 1996 to 2001, as the head of the patent and trademark department of Novartis in Basel, Switzerland. Since 2002, Konrad Becker has been an independent private practice patent attorney offering services to originator and generic pharmaceutical industry, focusing mainly on start-up companies. The author has no other relevant affiliations or financial involvement with any organization or entity with a financial interest in or financial conflict with the subject matter or materials discussed in the manuscript. This includes employment, consultancies, honoraria, stock ownership or options, expert testimony, grants or patents received or pending, or royalties.

No writing assistance was utilized in the production of this manuscript.

\section{Bibliography \\ - Reference}

1 Johnson A. The Community patent. Patent World (Informa Law). February 2002, pages 19-20.

\section{- Websites}

101 Pharmaceutical Sector Inquiry, Preliminary Report, European Commission, Competition DG, 28 November 2008 http://ec.europa.eu/competition/sectors/ pharmaceuticals/inquiry/preliminary _report.pdf

102 Sir Robin Jacob, Patents and Pharmaceuticals - a paper given on 29 November 2008 at the presentation of the Directorate-General of Competition's preliminary report of the pharma-sector inquiry http://ec.europa.eu/competition/sectors/ pharmaceuticals/inquiry/jacob.pdf

103 Annual Report 2007 of the European Patent Office, pages 8-11 www.epo.org/about-us/office/annualreports/2007/focus.html

104 European Commission, COM(97) 314 final, of 24 June 1997 http://europa.eu/documents/comm/green_ papers/pdf/com97_314_en.pdf 


\section{EDITORIAL | Becker}

105 Council of the European Union, Interinstitutional File 2000/0177 (CNS), 6843/1/03 PI 20, 3 March 2003 http://register.consilium.eu.int/pdf/en/03/ st06/st06843-re01en03.pdf

106 Council of the European Union, Interinstitutional File 2000/0177 (CNS), 7119/04 PI 28, 8 March 2004 http://register.consilium.europa.eu/pdf/ en/04/st07/st07119.en04.pdf

107 Future Patent Policy in Europe, Public Hearing - 12 July 2006, preliminary findings

http://ec.europa.eu/internal_market/ indprop/docs/patent/hearing/ preliminary_findings_en.pdf

108 European Patent Office www.epo.org/patents/law/legal-texts/ london-agreement/key-points.html

109 Luginbuehl S. A stone's throw away from a European Patent Court: The European Patent Litigation Agreement. E.I.P.R. 256-269 (2003).
110 Proposal for a Council decision establishing the Community Patent Court, COM (2003) 828 final, 2003/0324 (CNS) http://eur-lex.europa.eu/LexUriServ/ LexUriServ.do?uri=COM:2003:0828: FIN:EN:PDF

111 Revision of the European Patent Convention (EPC 2000). Official Journal of the European Patent Office. Special Edition 1/2007 www.epo.org/patents/law/legal-texts/ epc.html 